\title{
Foraminiferivory revisited: a preliminary investigation of holes in foraminifera
}

\author{
KURT SØREN SVENSSON NIELSEN
}

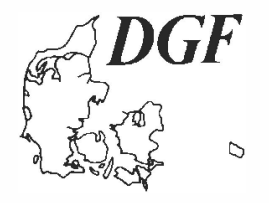

Nielsen, K. S. S.: Foraminiferivory revisited: a preliminary investigation of holes in foraminifera. Bulletin of the Geological Society of Denmark, Vol. 45, pp. 139-142. Copenhagen, 1999-01-30.

https://doi.org/10.37570/bgsd-1998-45-16

Planktonic and benthonic foraminiferal tests from modern tropical-subtropical marine environments were investigated with regard to bioerosional traces. The traces found on the foraminiferal tests were grouped into 7 different categories. It is suggested that the different traces may be related to different unknown preda-tors of which at least one is planktonic.

Key words: Foraminiferivory, predation, planktonic foraminifera, borings. K. S. S. Nielsen, Geological Institute, University of Copenhagen, Øster
Voldgade 10, DK-1350 Copenhagen K, Denmark. 23 September 1998.

The term foraminiferivory was introduced by Hickman \& Lipps in 1983 to cover the general phenomenon of ingestion of foraminifera. Little is known about the relationship between the predators and the foraminifera in modern communities. The problem is further complicated by the alleged uncertainties as to why foraminifera are eaten (Hickman and Lipps 1983, Walker 1971). Many fish (Daniels \& Lipps 1987, Lipps 1988) and macro-invertebrates are known to ingest foraminifera (Arnold et al. 1985, Berger 1971, Boltoskoy \& Zapata 1980, Brand \& Lipps 1982, Buzas and Carle 1979, Hickman \& Lipps 1983, Langer et al. 1995, Lipps et al. 1974, Mageau et al. 1975, Reyment 1966, Sliter 1971, and Walker 1971).All fish and most of the invertebrates do so incidentally. However, a few invertebrates (gastropods, nematodes and scaphopods) seem to prey selectively on benthonic foraminifera (Langer et al. 1995). Few of these animals leave traces on the foraminiferal tests and most tests are probably destroyed in the process of ingestion. In addition, a few reports exist on predaceous and parasitic foraminifera preying on other benthonic foraminifera (Banner 1971, Baumfalk et al. 1982, Cedhagen 1994, Freiwald \& Schönfeld 1996, Hallock \& Talge 1994, Plewes et al. 1993, Todd 1965, and Vénec-Peyre 1996).

\section{Results}

Holes in foraminiferal tests found in five samples from the Danish deep-sea expedition Galathea (1950-52) and two samples from the Gulf of Aqaba are here interpreted as predation of foraminifera through boring.
Almost all hitherto described examples of foraminiferivory involve either ingestion of or borings in benthonic foraminiferal tests. Based on the morphology of the holes found in the planktonic foraminifera it is possible to establish seven different categories. Group A: Circular to sub-circular holes (Figs 1, 2), Group B: Oval to sub-oval holes (Figs 3, 4), Group C: Pits (Figs 5, 6), Group D: Bite traces (Figs 7, 8), Group E: Circular to oval holes that end in a floor with a minute perforation (Figs 9, 10), Group F: Cupshaped holes (Figs 11, 12), Group G: Star-shaped holes (Figs 13, 14). None of the bored tests exceeds $350 \mu \mathrm{m}$ in size and in tests containing more than one boring the additional borings occur in separate chambers. All hole categories, except for group $\mathrm{G}$, were also found in benthonic foraminifera.

\section{Discussion}

It is assumed that most of the borings are the result of predation. Since the unknown predators seem to be size-selective relative to planktonic foraminifera, it is likely that the primary target for these predators is the cytoplasm in the foraminiferal test. The position of additional borings in separate chambers seems to support this suggestion. Bé \& Spero (1981) described repair processes in planktonic foraminifera when subjected to experimental damage of the test. No such structure has been observed in association with the borings and it is assumed that the foraminifera died from the attack. Since planktonic and benthonic foraminifera inhabit different environments it is most 

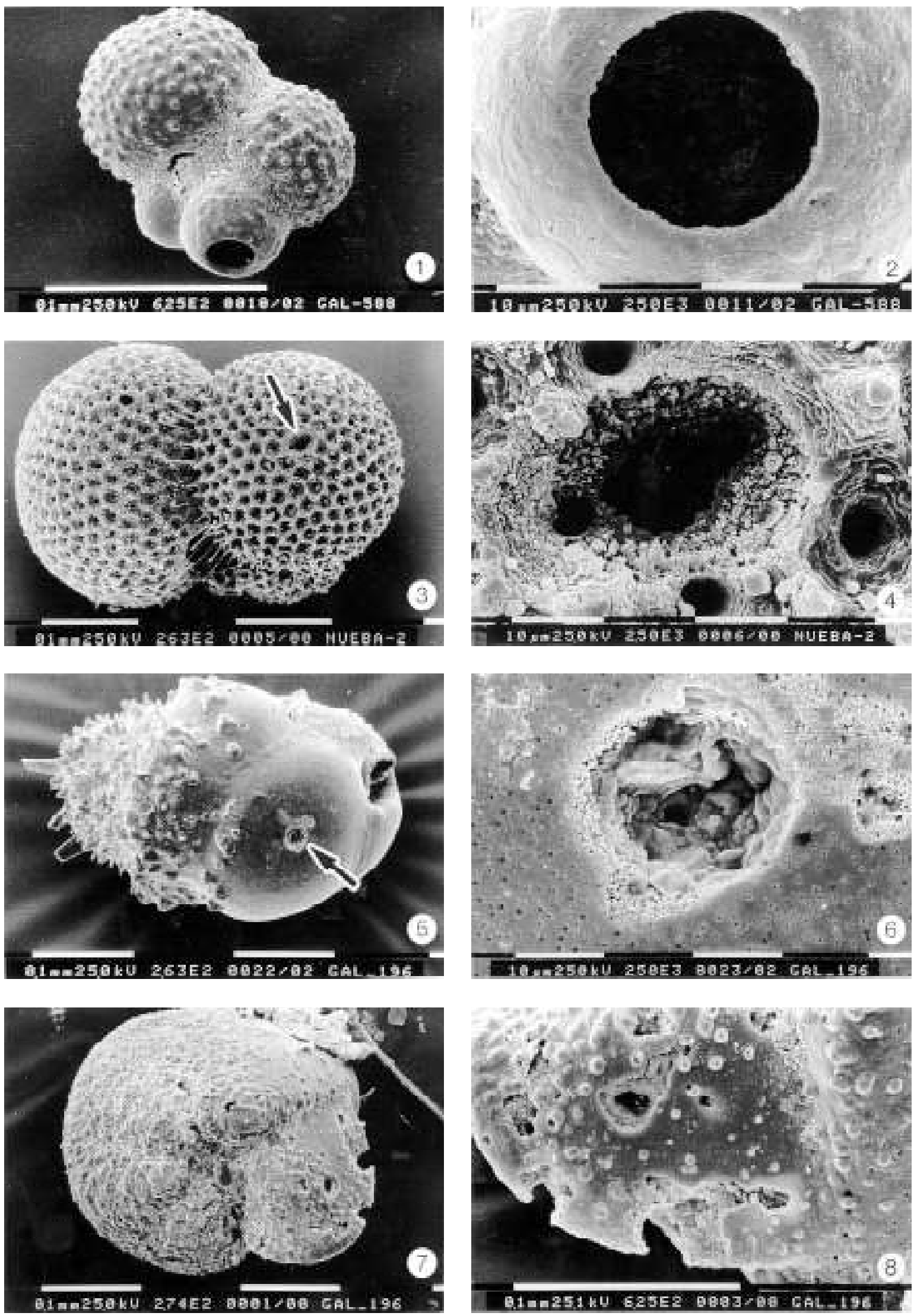

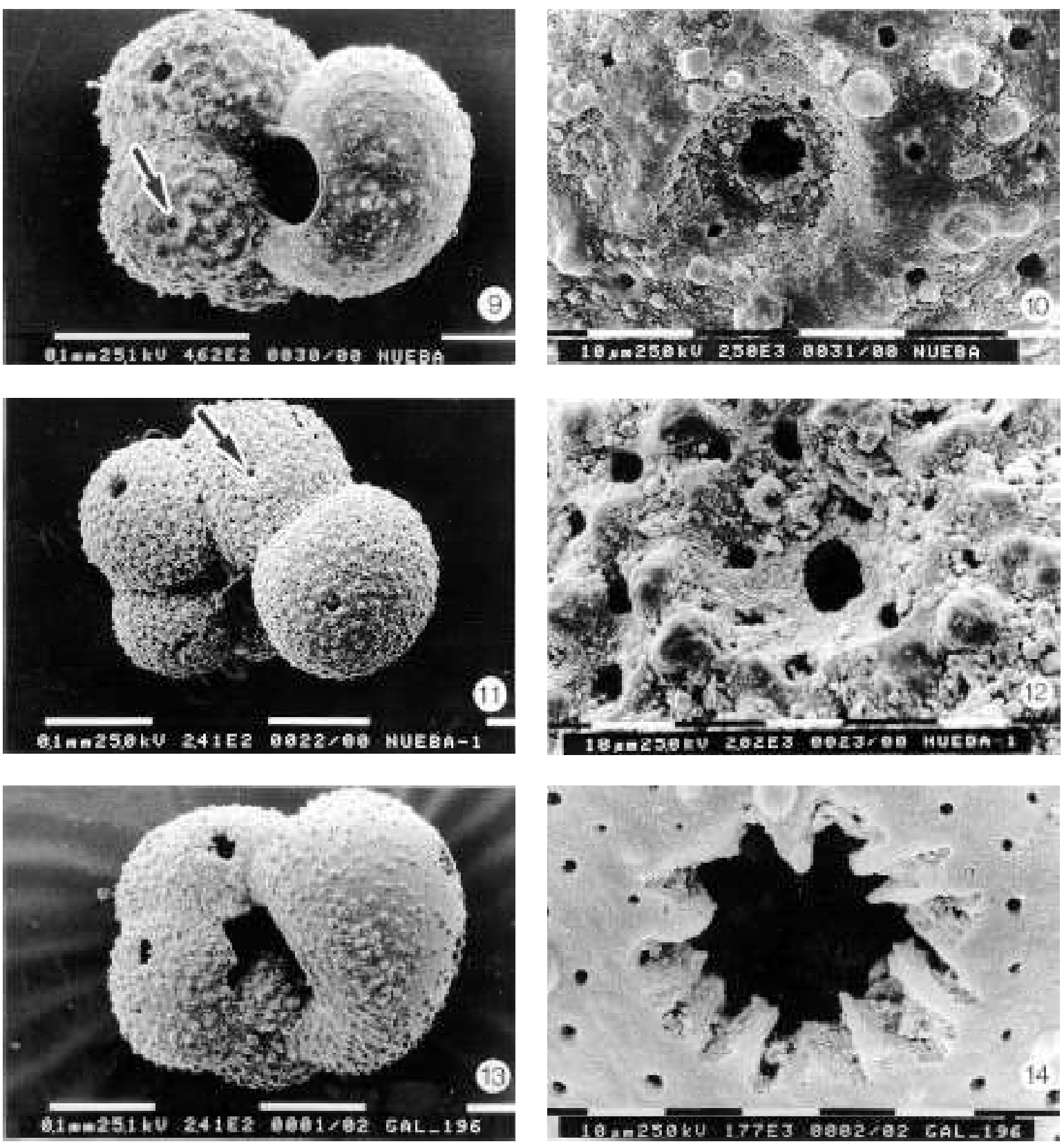

Figs 1-14. General and close-up views (see arrows). 1, 2: Group A. 3, 4: Group B. 5, 6: Group C. 7, 8: Group D. 9, 10: Group E. 11, 12: Group F. 13, 14: Group G. All figures except 5 and 6 are planktonic foraminifera. Scale at bottom of figures.

likely that at least two different predators are involved of which one is planktonic.

Acknowledgements

The author is indebted to Hans Jørgen Hansen (Copenhagen), who kindly provided the material used in this investigation and for helpful suggestions; Richard G. Bromley and Eckart Håkansson (Copenhagen), for their critical review of the manuscript and Jan Ågaard for helping with the pictures. 


\section{Dansk sammendrag}

Betegnelsen foraminiferivory blev i 1983 introduceret af Hickman \& Lipps for at dække det generelle fænomen, at nogle marine dyregrupper og fugle fortærer foraminiferer. Tidligere undersøgelser synes at indikere, at foraminiferer ikke har været et primært fødeemne for de fleste af disse dyregrupper. Analyser af maveindholdet fra nogle arter af rovsnegle og søtænder viser dog, at kalkskallede bentoniske foraminiferer udgør en betragtelig del af disse makroinvertebraters diæt.

For størstedelen af de foraminiferer, som bliver spist, gælder det formodentlig, at deres kalkskaller enten bliver knust af dyrets munddele, bliver opløst under fordøjelsesprocessen eller passerer igennem dyrenes fordøjelsessystem uden at der efterlades spor på skallen, der vidner om, at foraminiferen er blevet fortæret.

Prøver fra den danske Galatheaekspedition (19501952) og fra Aqaba bugten blev undersøgt med henblik på at påvise spor på kalkskallerne efter prædation på nulevende arter af planktoniske foraminiferer. De fundne spor kan morfologisk inddeles i 7 kategorier (A-G). Sporene er her tolket som værende af biogen oprindelse og menes dannet ved prædationsadfærd af et eller flere planktoniske rovdyr.

Hypotesen synes understøttet af den omstændighed, at de ukendte spordannere udvælger planktoniske foraminiferer af en størrelse, der er mindre end $350 \mu \mathrm{m}$, og at hvis der forekommer mere end et spor i skallen, er disse placeret i forbindelse med nye skalkamre.

$\mathrm{Da}$ alle kategorier af spor undtagen gruppe $\mathrm{G}$ også er påvist på kalkskaller af bentoniske foraminiferer er det muligt, at der er mere end to forskellige spordannere og at en af dem er et planktonisk rovdyr.

\section{References}

Arnold, A. J. d', Escrivan, F. \& Parker, W. C. 1985: Predatory and avoidance responses in foraminifera of the Galapegos hydrothermal mounds. Journal of Foraminiferal Research 15, 38-42.

Banner, F. T. 1971: A new genus of the Planorbulinidae, an endoparasite of another foraminifera. Revista Espasola De Micropaleontologia 3, 113-128.

Baumfalk, Y. A, Fortuin, A. R. \& Mok, R. P. 1982: Talpinella cunicularia n. gen., n. sp., a possible foraminiferal parasite of Late Cretaceous Orbitoides . Journal of Foraminiferal Reseach 12, 185-196.

Bé, A. W. H. \& Spero, H. J. 1981: Shell regeneration and biological recovery of planktonic foraminifera after physical injury induce in laberatory culture. Micropaleontology 27, 305-316.

Berger, W. H. 1971: Planktonic foraminifera: sediment production in an oceanic front. Journal of Foraminiferal Research 1, 95-118.

Boltoskoy, E. \& Zapata, A. 1980: Foraminiferos bentonicos como alimento de otros organismos. Revista Española de Micropaleontologia 12, 191-198.
Brand, T. E \& Lipps, J. H. 1982: Foraminifera in the trophic structure of shallow-water Antartictic marine communities. Journal of Foraminiferal Reseach 12, 96-105.

Buzas, M. A. \& Carle, K. J. 1979: Predators of foraminifera in the Indian River, Florida. Journal of Foraminiferal Research 9, 336-340.

Cedhagen, T. 1994: Taxonomy and biology of Hyrrokkin sarcophaga gen. et $\mathrm{sp}$. n., a parasitic foraminiferan (Rosalinidae). Sarsia 79, 65-82.

Daniels, R. A \& Lipps, J. H. 1978: Predation on foraminifera by antarctic fish. Journal of Foraminiferal Research $8,100-113$.

Freiwald, A. \& Schönfeld, J. 1996: Substrate pitting and boring pattern of Hyrrokkin sarcophaga Cedhagen, 1994 (Foraminiera) in a modern deep-water coral reef mound. Marine Micropaleontology 28, 199-207.

Hallock, P. \& Talge, H. K. 1994: A predatory foraminifera, Floresina Amphiphaga, n. sp., from Florida Keys. Journal of Foraminiferal Research 24, 210-213.

Hickman, C. S. \& Lipps, J. H. 1983: Foraminiferivory: Selective ingestion of foraminifera and test alterations produced by the neogastropod Olivella.. Journal of Foraminiferal Research 13, 108-114.

Langer, M. R., Lipps, J. H. \& Moreno, G. 1995: Predation on foraminifera by the dentaliid deep-sea scaphopod Fissidentalium megathyris. Deep-Sea Resarch 42, 849857.

Lipps, J. H. \& Ronan, T. E. 1974: Predation on foraminifera by the polychaete worm, Diopatra. Jounal of Foraminiferal Research 4, 139-143.

Lipps, J. H. 1988: Predation on foraminifera by coral reef fish. Taphonomic and evolutionary implications. Palaios 3, 315-326.

Mageau, C. N. \& Walker, D. A. 1975: Effects of ingestion of foraminifera by larger invertebrats. First international symposium on benthonic foraminifera of continental margiens. Part A. Ecology and Biology. Maritime Sediments, Special Publications 1, 89-105.

Plewes, C.R, Palmer, T.J. \& Haynes, J. R. 1993: A boring foraminiferan from the Upper Jurassic of England and Northern France. Journal of Micropalaeontology, 12, 83 89.

Reyment, R. A. 1966: Preliminary observationer on gastropod predation in the western Niger delta. Palaeogeography, Palaeoclimatology, Palaeoecology 2, 81-102.

Sliter, W. V. 1971: Predation on benthic foraminifera. Journal of Foraminiferal Research 1, 20-28.

Todd, R. 1965: A new Rosalina (foraminifera) parasitic on a bivalve. Deep-Sea Research 12, 831-837.

Vénec-Peyre, M. 1996: Bioeroding foraminifera: a review. Marine Micropaleontology 28, 19-30.

Walker, D. A. 1971: Etching of test surface of benthonic foraminifers due to ingestion by the gastropod Littorina littorea Linne. Canadian Journal of Earth Science 8, 1487-1491. 